\title{
Administrative Roles in Primary Schools for Curbing COVID-19 Pandemic in Nigeria: Henry Fayol's Approach
}

\author{
Igbokwe, Innocent. C, \\ Okeke-James, Ndidiamaka J., \\ Akudo, Florence U., \\ Anyanwu, Jude A., \\ Department of Educational Management and Policy \\ Nnamdi Azikiwe University, Awka, Anambra State, Nigeria
}

URL:http://dx.doi.org/10.19044/esj.2020.v16n16p63

\begin{abstract}
COVID-19 is a threatening disease that has led to total lockdown of educational institutions in various countries, Nigeria inclusive. Presently, there is no vaccination for its cure yet; thus, the need for preventive mechanisms to reduce its spread in the schools. The primary school which this study is delimited is made of pupils whose ability to prevent this disease is minimal due to their level of physical and mental development, therefore they require proper attention. The headteachers and teachers who occupy administrative positions in primary schools need to manage these pupils, to prevent the spread of coronavirus in the schools. The main purpose of this study is to suggest how headteachers and teachers should practically discharge their administrative functions so as to reduce coronavirus spread among pupils in primary schools. This is expected to give an insight into healthy adaptive mechanism for the staff and pupils in primary schools in Nigeria. Finally, the following recommendations were made; which include: providing hygiene facilities, services of healthcare workers and isolation center in the school for pupils that may need extra care.
\end{abstract}

Keywords: Covid-19, Headteachers, Classroom teachers, primary education

\section{Introduction}

Educational system in Nigeria has been faced with various challenges such as poor funding and managerial issues. This leads to decay in the educational system. It also leads to incessant strike among teachers. One of such strike actions just commenced on March 2020 in tertiary institution in the 
federation. Notwithstanding, the outbreak of COVID-19 pandemic has also triggered the ban of social organizations such as business organizations, church and educational institutions, among others. Government ban on social organizations have hindered the operation of educational activities which brough about sit at home for both the teachers and learners.

Recently, the federal government gradually eased the restrictions which includes reopening of schools. According to Nigerian Tribune news on $30^{\text {th }}$ April, 2020, the Head of Service (HOS) Dr. Folasade Yewmi-Esan gave directives that federal government offices are to reopen three times a week. Honourable Commissioner for Basic education in Anambra State announces that schools will reopen on Monday $4^{\text {th }}$ May 2020 without students. He maintained that only teachers will resume arranging on how to apply the COVID-19 policy in the schools before the students will join them

Consequently, the news that schools will resume earnestly was received by parents and guardians of pupils in primary schools with mixed feelings. There is no doubt that it will be good for pupils to return back to school after the unplanned long stay at home due to the pandemic. However, the parents and guardians are apprehensive that if enough precautionary measures are not put in place in the schools the spread of the virus will be so overwhelming. The chunk of the responsibility rests on both the headteachers and classroom teachers. To this end, this paper examines the administrative roles of head teachers and classroom teachers in the bid to reduce coronavirus spread in primary schools. This is expected to give an insight to school administrators on adaptable health preventive mechanisms to reduce the coronavirus upsurge while discharging their core administrative duties in the school.

\section{Coronavirus}

The truth in blueprint is that COVID-19 has no known vaccination for its cure yet. Thus, the need for essential carefulness to reduce its spread. COVID-19 is a disease that was traced to Wuhan, Hubei, China in the year 2019. It was named COVID-19 to distinguish this particular disease from other known coronaviruses. COVID-19 stands for:

$\mathrm{CO}=$ Corona

$\mathrm{VI}=\mathrm{Virus}$

$\mathrm{D}=$ Disease

19=2019. Identified in the year 2019

Coronavirus is an infectious disease that is transmitted from human to human. It is a virus that is spread by droplet released from an infected person. It has been estimated to have an incubation period of 14 days. According to World Health Organization (WHO,2020), there have been various known coronavirus that cause illness ranging from the common cold to more severe 
diseases such as severe acute respiratory syndrome (SARS) and the Middle East respiratory syndrome (MERS). But the nature of this particular Ccovid19 will be better understood by looking at its symptoms and effects on the body. Some of the symptoms of COVID-19 include: common cold, pains, sore throat, headache, chest pain, kidney failure, difficulty breathing, pneumonia, diarrhea and nausea, among others. Among its grave effects include: heightened level of carbon dioxide in the body, respiratory illness, inability of the body to filter the blood, kidney failure and death.

The figure below depicts the symptoms to check out for in a COVID19 infected person.

Figure 1: Fish bone Diagram of COVID-19 Symptoms

Fish-Bone Diagram of Full List of Symptoms of COVID-19

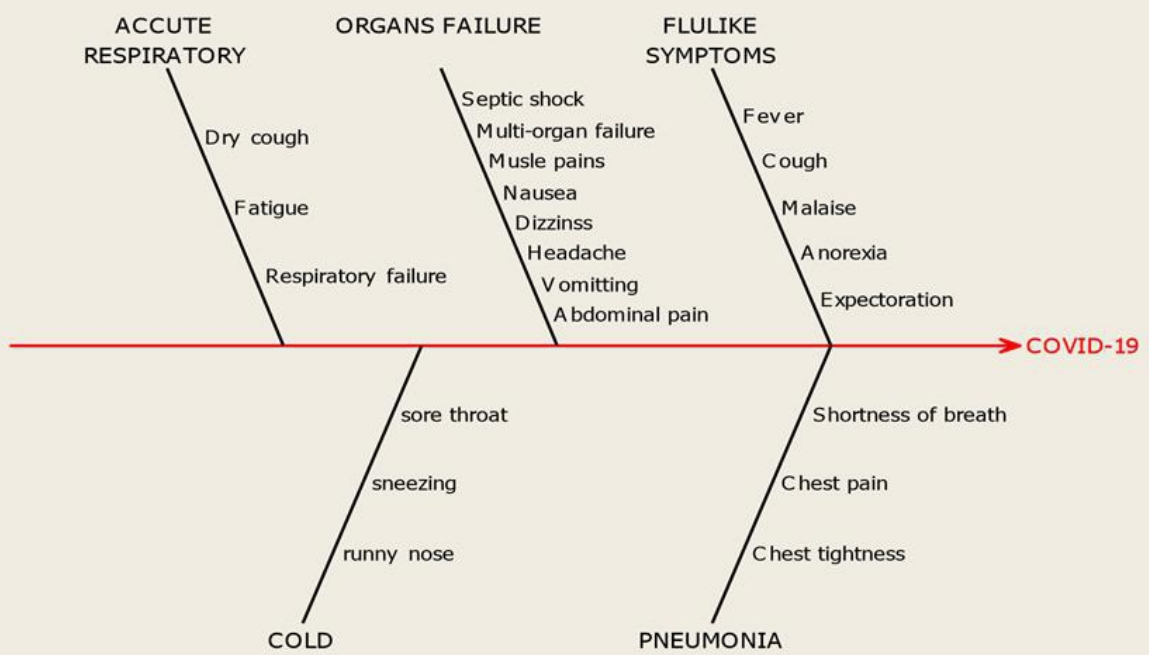

Source: Odunayo (2020)

In Nigeria, the Nigeria Centre for Disease Control (NCDC) on May 3, 2020 has recorded about 2388 confirmed cases, 385 recovered and 85 deaths. There are indices of persistent increase in the cases of COVID-19 spread. To this effect, Nigeria government has deployed various prevention and management mechanism to reduce the spread of the disease. Such as: closure of schools, nationwide lockdown, bans of public gathering (church, markets, bank, restaurants, wedding, meeting, social events, conference, seminars, and workshops), curfew, mandatory sit at home, and restrictions on travels; among others, all in the bid to reduce COVID-19 spread. Despite the efforts by the government, the rising trend of the infection in the country continues unabated. 


\section{Trend Analysis}

Figure 2 below shows trend plot for the pattern of outbreak of COVID-19 in Nigeria.

Figure 2: Trend Plot of Both Active and Daily Confirmed Cases are on Increasing Trend Since 11th March till date

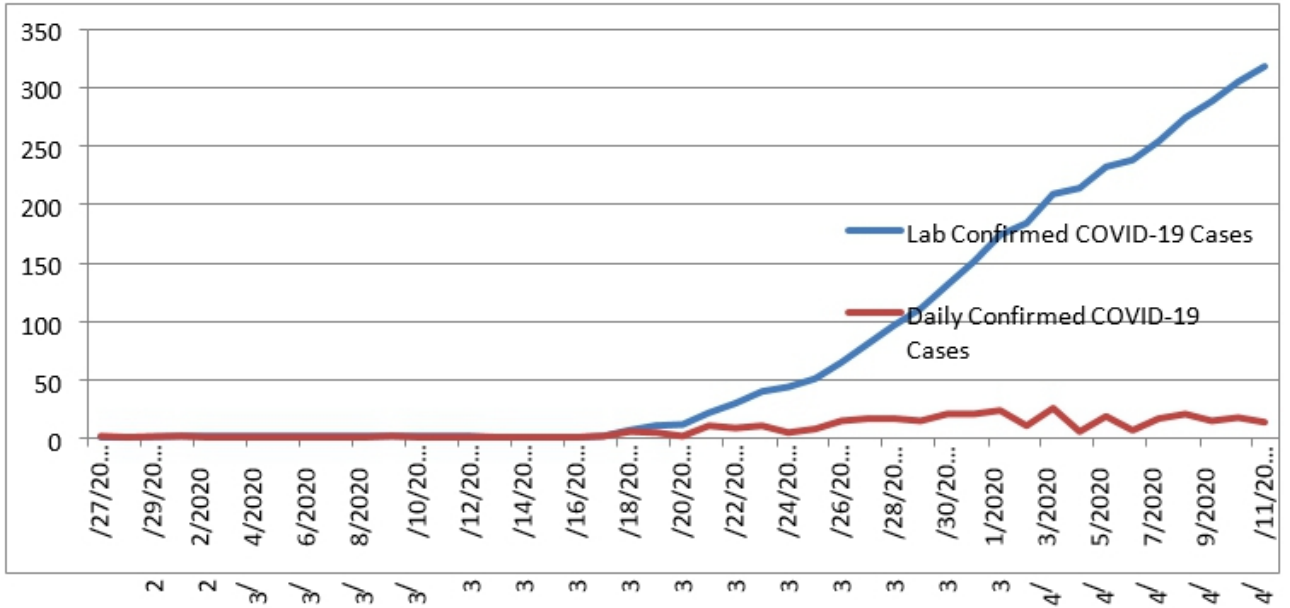

Source: Odunayo (2020)

Figure 3: Linear Trend plot for COVID-19 Outbreak in Nigeria

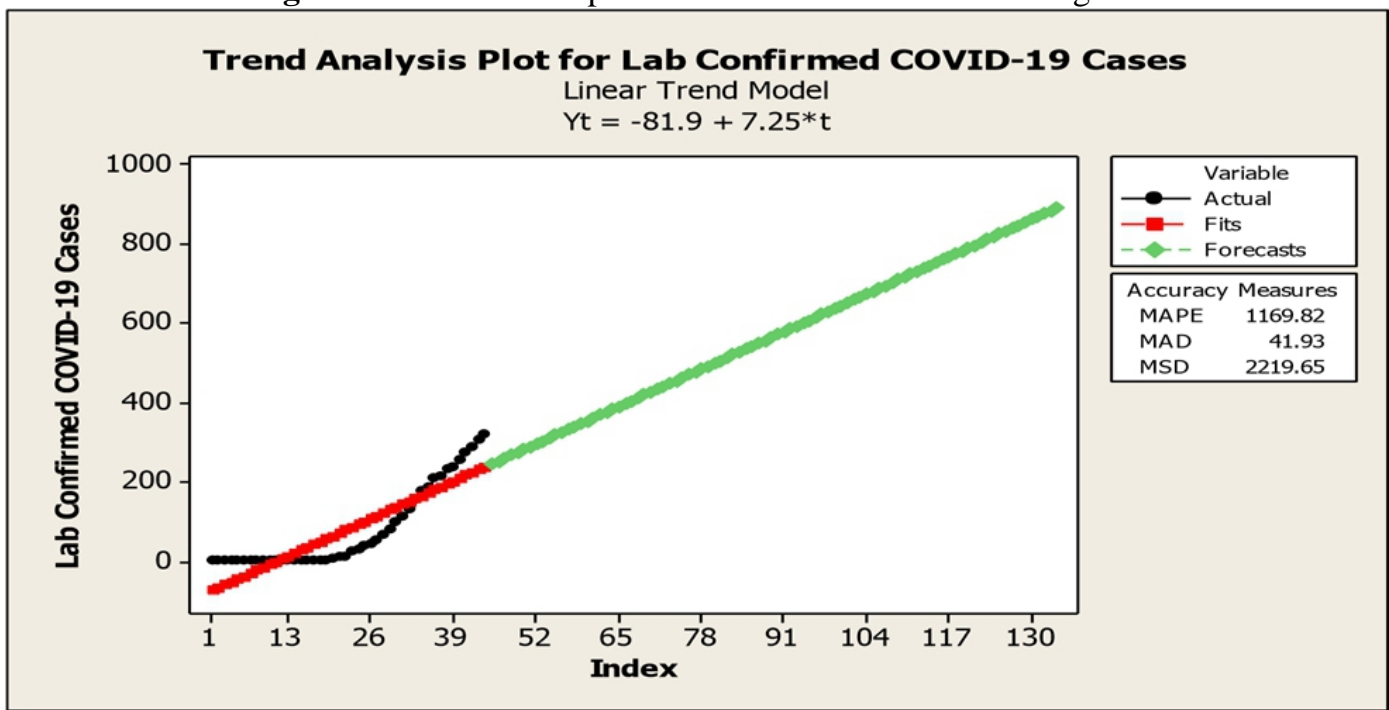

Source: Odunayo (2020)

Infact, using linear trend model $\left(Y_{t}=-81.9+7.25\right.$ time $)$, Odunayo (2020) shows that if more intervention is not put in place in Nigeria to curb to spread of coronavirus, that Nigeria might record close to 1000 cases in the next 90 day from 11th April 2020. This prediction became accurate. The case of infection as released on June $3^{\text {rd }}$ by Nigeria Centre for Disease Control 
(2020) reported 10,819 confirmed cases, 7,266 active cases, 314 death and 65,885 tested.

Presently, Nigerian government has partially lifted the lockdown and bans starting from June 2, 2020 with few restriction protocols. Thus, average Nigerians speculate that they can freely go about their businesses provided the meet up with the government protocol which include wearing of face mask and social distancing. Many Nigerians fail to realize that if proper care is not taken there will be an outrageous increase in spread rate in primary schools where the children will not be able to wear mask. To this effect, the managers of education institutions; primary education in particular requires to take proactive measure to curb possible spread of this deadly pandemic among pupils. Head teachers, therefore, ought to strategically discharge their roles as academic and administrative heads in the school. As such this paper is out to proffer healthy adaptive mechanisms for healthy school environment to reduce coronavirus outburst among staff and pupils in primary schools.

\section{Primary Education}

Primary education is the foundational schooling for extending any educational building. According to Federal Government of Nigeria in the National Policy on Education (NPE, 2013), primary education is tuition free, universal and compulsory education given in institution for children aged 6 to 11 plus. It is an education acquired in six years duration. Its objectives according to (NPE, 2013) include to:

i. $\quad$ lay sound basis for scientific, critical and reflective thinking;

ii. promote patriotism, fairness, understanding and national unity;

iii. develop in the child the ability to adapt the changing environment;

iv. provide opportunities for the child to development life manipulative skills that will enable the child function effectively in the society within the limits of the child's capability.

In pursuance of the above primary educational objectives, particularly grooming the child to adapt to the changing environment, which is envisaged as preparing pupils to adapt to climate change; of which coronavirus pandemic is perceived as one of such environmental change. And also, the enormous duty of managing the population of over $75 \%$ of Nigerian children due to universal, mandatory and unconstrained tuition fee in primary education. The plight of this study therefore, is considering the age bracket of pupils in primary school and the limited health knowledge of these pupils; there is a great need for effective school administration to ensure proper health caution and proper carefulness especially in this era of coronavirus outbreak.

Two important education stakeholders charged with the responsibility of primary school administration are the head teachers and classroom teachers. 
The classroom teachers are the group of people charged with the responsibility of teaching, training, encouraging and inspiring the pupils to learn (OkekeJames, Igbokwe, Anyanwu \& Obineme, 2020). Igbokwe, Okorji and Asiegbu (2016), holds the view that every professional teacher has the right to participate in the wider decision-making process in an open school climate. More strongly, classroom teachers are not just charged with the responsibility to impact knowledge and skills on pupils but also to guide, teach, motivate and look after them (Okeke-James, Igbokwe, Ogbo, Ekweogu \& Anyanwu, 2020). The headteacher is the most senior teacher, leader and administrator in primary education. The leadership role of the headteachers like the school principals comprises both personnel management, administrative function and decision making (Okorji, Igbokwe, \& Ezeugbor, 2016). The headteacher is the most senior teacher, leader and administrator in primary education. As an administrator he oversees educational programmes and provides a guild for effective daily administration of the school. According to Craige (2018) the role of educational administrators include: setting the institution's tone, setting policy that staff and students will abide by. Henry Fayol (1845-1925) outlined five administrative functions which are as follows: planning, organizing, directing, coordinating and controlling. In this study, the researchers used the administrative functions outlined by Henry Fayol to proffer preventive health mechanism in coronavirus and post coronavirus pandemic in primary schools in Nigeria.

\section{Headteachers' Application of Fayol's Administrative Functions in Primary Schools}

The following are practical ways headteachers can apply Fayols' administrative functions (planning, organizing, directing, coordinating \& controlling) to curb Coronavirus spread in the school.

\section{Application of Planning in the School:}

This is the process of setting or making detailed ideas on how to achieve the set primary education goal. According to Okwori, cited in Nwogbo (2014), planning is an intelligent process of preparing or arranging a set of decisions for future action directed at achieving goals and objectives by best possible means or methods. Application of this function in the school requires that the headteacher should design the ways and means of reducing coronavirus spread in the school. The preventive method should involve the following:

i. Identifying the Hygiene Facility's Needs: There is need for proper identification of areas of poor hygiene facilities in the schools. It is reasonable to note things or areas like drinking water, rest rooms (if possible, bathing rooms), disinfectant, detergent, and hand sanitizers, 
face masks, fumigating school compound, healthcare services and facilities. It is important to involve healthcare experts for proper guidance.

ii. Deploying of Resources: There is need to source information, draw up a budget by making market survey from reliable source in order to make purchases and supply of the hygiene facilities

iii. Participation: To accomplish the above, there is need to involve other education stakeholders, thus joint participation of other stakeholders is of great important to achieving health goal.

\section{Application of Organizing in the School:}

This is the process of specifying and arranging the planning functions in achievable order. According to Abulkareem and Oduwaye (2017), organizing involves arranging activities and resources for effective classroom behaviour and performance. The headteacher can achieve this through assigning duties to school staff like posting the hygiene rule at strategic places in the school, especially at the school gate, integrating the school hygiene rules to parents or guardians, assigning a staff to ensure that adherence to the hygiene rule is a guarantee for gaining entrance to school premises and updating of parents contact numbers and address in case of health emergency need, ensuring contact lines of health workers.

\section{Application of Directing in the School:}

Directing is to ensure that staff perform their duties and pupils exhibit expected hygiene behaviours in the school. The headteacher should apply this through provision of hygiene facilities in every classroom, library, offices, play ground, adequate supervision and monitoring to ensure that none of the hygiene facilities or behaviours is ignored by staff, parents and pupils.

\section{Application of Controlling in the School:}

According to Oyedeji (2017), coordinating is function that is targeted at eliminating all forms of waste (time, materials \& funds) so as to meet the set standard. The headteacher should ensure proper health records and purchases inventory for proper accountability. He also should ensure the provision for portable water, washing soap (preferably liquid soap), hand sanitizer, tissue, reserved mask for staff and pupils.

\section{Application of Coordinating in the School:}

This is steering the activities of all stakeholders' efforts geared towards curbing COVID-19 spread in the school. The headteacher will achieve this function by: regularly fumigating the school environment, ensure proper disposal of waste preferably through incineration, creating steady COVID-19 
awareness in the school using manual and electronic device (computer, projector, television \& healthcare workers) etc.

\section{Classroom Teachers' Application of Fayol's Administrative Functions}

Teachers are the classroom managers and as such perform administrative functions in the classroom. These are ways of curbing the spread of coronavirus in primary school by teachers using Fayol's administrative functions.

\section{Application of Planning in the Classroom:}

Classroom planning is process of making decision on what to teach and how to teach it successfully (Ezeugbour, Okeke-James \& Emengin, 2019). The teacher achieves this by: decongesting crowded classroom and making provision of classroom hygiene facilities (toiletries, disinfectants) in the classroom.

\section{Application of Organizing in the Classroom:}

The teacher achieves this by mapping classroom hygiene rules and penalty for defaulters, strategically sandwiching COVID-19 awareness in lesson notes, class work and assignments. Also, ensure that pupils sit quietly in their seats and maintain social distance in the classroom.

\section{Application of Directing in the Classroom:}

The teacher ensures adequate supervision through exemplary healthy living and behaviour for pupil to emulate. The teacher should ensure frequent hand washing in the class.

\section{Application of Controlling in the Classroom:}

The teacher should ensure adequate classroom hygiene evaluation such as: ensuring that pupil eat their snack, food or water alone, washing of hands before entering into the classroom, mandatory use of cloth face mask as a criterion for entrance to classroom.

\section{Application of Coordinating in the Classroom:}

The teacher ensures classroom control, that pupils maintain hygiene behaviours such as: cover nose and mouth when sneezing, avoidance of close or body contact with your friends and minimizing class noise in the classroom. The teacher should ensure that pupils take permission whenever there is need to go out from the class. 


\section{Conclusion}

Healthy training and habits are among essential prerequisite for reducing COVID-19 spread in the primary schools. This is because the age bracket of primary school pupils is often faced with physical and psychological demands, also they learn easily through emulation of their headteachers and classroom teachers.

\section{Recommendation}

With the above administrative functions, headteachers ensure acquiring hygiene facilities where they are not sufficient and the classroom teachers should instill hygiene consciousness and information to pupils while they also maintain healthy hygiene habits and behaviours. Also, recommendations were made with regard to providing hygiene facilities, services of healthcare workers and isolation center in the school for pupils that may need extra care. Finally, e-learning should be encouraged at all levels of education in Nigeria.

\section{References:}

1. Abulkareem, A.Y \& Oduwaye, R.O. (2017). Concepts, principles and functions of educational management. Educational management: New perspectives. Amfitop books, Apapa-Lagos.

2. Craige, A.P. (2018). Definition of educational administration. Retrieved from https://www.theclassroom.com

3. Ezeugbor, C.O, Okeke-James, N.J. \& Emengini, B. (2019). Teachers' classroom management techniques: a panacea for enhancing students' academic performance in secondary schools. Unizik Journal of Education Graduate 6(1).215-222.

4. Ezeugbor, C.O, \& Anozie, P. O. (2019). Educational management and new dimension. SCOA Heritage publications. Awka.

5. Igbokwe, I. C., Okorji, P. N., \& Asiegbu, E. C. (2016). School climate dimensions as predictors of principals' job performance in secondary schools in Enugu State, Nigeria. Journal of Educational Policy and Entrepreneurial Research, 3(7), 106-114.

6. Nigeria Centre for Disease Control (2020). Covid 19 in Nigeria. Retrieved on $3^{\text {rd }}$ June, from 2020Covid19.ncdc.gov.ng/\#!.

7. Nwogbo, V.N. (2014). Basic concepts in educational administration and management In Unachukwu, G. O \& Okorji, P.N.(Eds.). Educational management: A skill building approach. Nimo, Rex Charles and Patrick Limited.

8. Odunayo, B. J. (2020). On the monitoring of coronavirus disease 2019 (covid -19) pandemic outbreak in Nigeria. African Journal of Biology and Medical Research, 3(2), 33-40. 
9. Okeke-James, N. J., Igbokwe, I. C., Anyanwu, A. N. \& Obineme, O. P. (2020). Gender influence on school climate and organizational silence amongst teachers in Anambra State. European Scientific Journal, 16(10), 223-237. Doi:10.19044/esj.2020.v16n10p223 URL:http://dx.doi.org/10.19044/esj.2020.v16n10p223

10. Okeke-James, N. J., Igbokwe, I. C., Ogbo, R. N., Ekweogu, L. B., \& Anyanwu, A. N. (2020).

11. School climate as a predictor of teachers' job performance in secondary schools in Anambra State, Nigeria. International Journal of Education and Research, 8(3), 17-26.

12. Okorji, P. N., Igbokwe, I. C. \& Ezeugbor, C. O. (2016). Relationship between school climate and principals' job performance in secondary schools. European Scientific Journal, 12(4), 55-67. doi: 10.19044/esj.2016.v12n4p55

URL:http://dx.doi.org/10.19044/esj.2016.v12n4p55

13. Oyedeji, N. B. (2017). Management theories and their applications to school administration. Educational management: New perspectives. Amfitop books, Apapa-Lagos.

14. World Health Organization (WHO, 2020). There is a current outbreak of coronavirus (COVID-19) disease. Retrieved from https://www.who.int/health-topics/coronavirus\#tab=tab_1 